Volume 13 Number 4, October-December 2019: pp. 307-320. Copyright (c) 2019 FIAT JUSTISIA. Faculty of Law, Lampung University, Bandarlampung, Lampung, Indonesia. ISSN: 1978-5186 | e-ISSN: 2477-6238. Open Access: http://jurnal.fh.unila.ac.id/index.php/fiat

Fiat Justisia is licensed under a Creative Commons Attribution 4.0 International License, which permits unrestricted use, distribution, and reproduction in any medium, provided the original work is properly cited.

\title{
Theoretical Review: The Protection of Music Copyrights in the Radio
}

\author{
Wahyu Sasongko \\ Universitas Lampung, Indonesia \\ wahyusasongko@gmail.com
}

\begin{abstract}
Playback of music or songs on the radio has the potential to infringe the copyright songwriters. Based on the applicable legal provisions, namely Law Number 28 the Year 2014 concerning Copyrights, the songwriter is the copyright owner of music which is protected by law. Therefore, parties who take advantage of music must obtain permission from the copyright owner. Radio companies should get permission from the copyright owner to play the music on their radio station. However, it is difficult to oversee the playback of the music on the radio. In this context, a collective management agency (CMA) emerges, but the presence of a CMA is not mandatory or optional. Therefore, this paper does not involve CMA. In this regard, legal issues arise, namely how to protect music copyrights according to applicable law to attain legal certainty. This paper is a theoretical study of legal theory or legal doctrine relating to the rights of songwriters. In legal science or jurisprudence it is not clearly distinguished between legal doctrine and legal theory. In discussing this issue, firstly it will be discussed about the meaning and types of music copyrights. Next, it will be discussed about the legal construction or legal framework of music copyrights. Based on theoretical studies, songwriters have various rights with specific characteristics so that the treatments must also be accurate. The legal construction of music copyrights is intertwined in a network of legal binding that is influenced by subject and object factors. The subjects involved are interconnected to use the music as its object. The legal relationship between subjects is mutually beneficial or mutual symbiosis. Meanwhile, music as objects is a flexible commodity. Therefore, airing music on the radio is in doubt to be categorized as copyright infringement.
\end{abstract}

Keywords: Legal Protection, Music Copyrights, Economic Rights, Moral Rights. 
How to Cite: Wahyu Sasongko, "Theoretical Review: Protection of Music Copyrights in the Radio ”, Fiat Justisia, 13 (4), (2019).

DOI: 10.25041/fiatjustisia.v13no4.1814

\section{A. Introduction}

Radio is one of the communication and information media that still exist and survive amid the rapid development of communication and information technology. ${ }^{1}$ Although information and communication technology has been so sophisticated, the role of radio as a tool of mass communication is still a choice or alternative for people who need information and entertainment. It can be said that along with the progress of the era, the development of radio has also increased rapidly. In the operation of Komisi Penyiaran Indonesia or Indonesian Broadcasting Commission, radio has spread to various remote areas of Indonesia, both government and private radio. ${ }^{2}$ Based on data from the Indonesian Broadcasting Commission, the number of radios in 2017 has reached a significant amount, reaching 4,050 consisting of 3,317 private radios, 244 public radios and 489 community radios. On average, each city in Indonesia has approximately ten radios, including private, public and community. The highest number of radios is on Java Island. ${ }^{3}$

The radio becomes important because basically, the radio is a mass electronic communication media. Radio can be heard by many people at the same time so that the information conveyed can be received by many people simultaneously. This privilege is seen by presenting environmental issues, conservation, and global warming, which is presented easily to be understood. ${ }^{4}$ Communities in rural areas need information relating to agriculture in a broad sense, including plantations, animal breeding and fisheries. Besides, they also need entertainment in the form of music or songs, radio plays and so on. Likewise, people in cities listen to the radio to search the information they need. For those who are experiencing traffic

1 Ulia, Abdullah Karim, Andik Riyanto, "Persepsi Pendengar Radio Anggota Forum Komunikasi Pemerhati Terhadap Siaran Opini Publik "Selamat Pagi Kaltim" di Pro. 1 Lembaga Penyiaran Publik Radio Republik Indonesia Samarinda", eJournal Ilmu Komunikasi, 6 (4), (2018), p.165.

${ }^{2}$ M. Nasor, "Optimalisasi Fungsi Radio Sebagai Media Dakwah”, Al-AdYaN, XII (1), (2017), p.106.

3"KPI Ingatkan Radio Hilangkan Kata Kasar dan Lirik Cabul"; https://www.republika.co.id/berita/ nasional/\%2010umum/18/11/09/phxgel328-kpi-ingatkan-radio-hilangkan-kata-kasar-danlirik-cabul, accessed on $10^{\text {th }}$ July 2019.

${ }^{4}$ Demmy Prima, "Fungsi Korelasi RRI Program Pro 1 Lestari Alamku dalam Meningkatkan Kepedulian Lingkungan Hidup di Kota Samarinda", eJournal Ilmu Komunikasi, 4 (1), (2016), p. 302. 
jams, they will look for information about a jammed road route as an anticipation effort or avoidance. They also seek entertainment by listening to music to eliminate the boredom of facing traffic jams.

Radio entertained its listeners by giving a variety of programs. Thus radio was also chosen as a means of entertainment by presenting music programs, infotainment and news. ${ }^{5}$ Regarding the data on the number of radios aforementioned, the playback of songs as an entertainment of radio is highly intense, almost every time the songs are played. Legal protection of song copyrights owner on the radio is increasingly important and urgent. Songs that are played on the radio are copyrighted works or the works of songwriters that are protected by Copyright Law. The radio company benefits from playing songs on its radio station. More and more fans who listen to broadcasts from radio stations will attract companies to put advertisements on the radio. Meanwhile, the songwriters that are played on the radio should also receive rewards from playing the songs on the radio.

Songwriters by the provisions in Indonesian Law No. 28/2014 on Copyrights have the authority or permission to transfer or permit other parties to duplicate their songs/music, including broadcasting. The permit is granted through a legal agreement mechanism or commonly known as a licensing contract. A license is a form of giving a licence to utilise an intellectual property right that can be gained by the licensor to the licensee. The licensee then could perform a business activity, either in the form of technology or knowledge to produce, sell, and other certain service activities, by using the licensed intellectual property rights. ${ }^{6}$ Therefore, songwriters can arrange licensing contracts with song record companies and radio companies. Radio companies have the potential to violate the rights of songwriters if they do not hold permission or licenses from songwriters. This kind of situation creates legal uncertainty.

In this connection, a legal problem arises, namely how to protect the copyright of music according to the applicable law and to discuss the issue, firstly it will be discussed about the meaning and types of copyright owned by the songwriters. Next, it will be discussed about the legal construction or legal framework of music copyrights protection. Through this discussion, a comprehensive understanding of song copyrights protection on radio can be obtained which is not only the creator who is protected but the radio company can also avoid violating the law.

\footnotetext{
${ }^{5}$ Ruth Dikta Novriska, "Manajemen Siaran Musik Pada Music Director Radio Fresh 94,3 FM Pekanbaru dalam Mempertahankan Eksistensi", JOM FISIP, 3 (2), (2016), p.2.

${ }^{6}$ Rezky Lendi Maramis, "Perlindungan Hukum Hak Cipta Atas Karya Musik dan Lagu Dalam Hubungan Dengan Pembayaran Royalti”, Lex Privatum, II (2), (2014), p.118.
} 


\section{B. Research Methods}

This study uses a theoretical or doctrinal review with a normative legal problem approach (library law research) with a descriptive-analytical type of research. The data obtained are secondary data from sources such as literature, articles and internet sites.

\section{Discussion}

\section{Meaning and Types of Copyright in Indonesia}

Hak Cipta (grammatically in English as copyright) according to the concept of Indonesian law is not a translation of the United Kingdom concept of copyright, but it is a translation of the terms auteur recht (Dutch), droit d'auteur (French), or author's right, which means the rights to author which it develops for the creator. On the other hand, copyright can be translated as the right to copy. ${ }^{7}$ However, according to Article 1 of Law No. 28/2014 on Copyrights, "copyrights" is an exclusive right held by the creator of a work which is entitled automatically through a declarative principle after creation is realised physically without decreasing any limitation regarding regulations. The mentioned exclusive right is defined as an inviolable right without the creator's permission. ${ }^{8}$

Reviewed epistemologically, copyright is a branch of the Law of Intellectual Property Rights in the fields of science, arts and literary.

Meanwhile, intellectual property rights (IPRs) are legal rights resulting from intellectual activities in the areas of industry, science, literature and art or which are artistic in nature. Those rights do not apply to physical objects where creation can be realized but to objects that do not manifest. ${ }^{9}$

According to the prevailing legal system in Indonesia, which is influenced by the Dutch legal system, it is distinguished between public law and civil law. In this context, IPRs is a branch of Civil Law that regulates relations between legal subjects in specific fields or fields of law, namely: (a) person law (persoonenrecht); (b) family law (familierecht); (c) property law (vermogenrecht); (d) inheritance law (erfrecht).

Meanwhile, property law is divided into two. First, the law of things (zakenrecht) which regulates the legal relationship between the legal subject (person) and legal object (property) in the form of property rights. Second, the law of obligations (verbintenissenrecht) which regulates the legal

\footnotetext{
${ }^{7}$ Bertrand Russell, Power: A New Social Analysis, New York: W.W. Norton \& Company, Inc., (1966), p. 135.

${ }^{8}$ Ade Uswatun Sitorus, "Hak Cipta dan Perpustakaan", Jurnal Iqra', 9 (2), (2015), p.253.

${ }^{9}$ Ibid., p. 3.
} 
relationship between legal subjects in the form of individual rights. ${ }^{10}$ The property rights have absolute characteristics, namely the property rights follow things or goods as objects of rights wherever they are. In this case, property can be distinguished based on their personalities, namely moving property and immovable property or based on their forms, namely tangible property and intangible property. Thus, property rights on movable objects such as vehicles can move along because they are attached to the object.

Individual rights are relative, meaning that individual rights arise because of interpersonal legal relationship. For example, a legal relationship in the form of a transaction or agreement on the sale of goods, the subject of legal relationship is the seller and the buyer. Everything that happened between them can only be solved by the two of them. This personal relationship in legal theory is called the privacy of contract. ${ }^{11}$

In the context of copyright, property rights regarding works as copyrighted objects include scientific books, novels, music, paintings. Meanwhile, individual rights pertaining to the transfer of rights to another party through an agreement or transfer of copyright or simply giving permission or license to reproduce or perform work.

Music/song copyrights are an intangible object and are treated as a movable object because even though the music/song is intangible and can only be heard, it can be translated into real forms, such as vinyl records, vocal cords or cassettes, CDs (compact discs), and USB. Thus, the music/song copyrights are attached to the tangible movable $\mathrm{CD}$. In this case, it needs to be differentiated between the ownership of the music/song and the ownership of the goods (Vinyl, CD, etc.) as the medium of music/song. Someone who buys a CD does not mean purchasing copyright on music/song, but only own to the CD physically. So, he/she has no right to reproduce, rerecord the music/song and republish it. ${ }^{12}$ If someone copies music/song without permission from the songwriter by putting the copy of music/song to a new $\mathrm{CD}$, the songwriter can ask law enforcement officials to confiscate it.

The meaning and concept of copyright according to Indonesian Law No. 28/2014 on copyrights are the exclusive rights of the creator that arise automatically based on the declarative principle after work is fixed in tangible form without reducing restrictions by statutory provisions (see, Art. 1 Section 1). The main characteristic of copyright is the exclusive right,

\footnotetext{
${ }^{10}$ Henk Snijders and Jaap Hijma, The Netherlands New Civil Code, Jakarta: National Legal Reform Program, (2010), p. 33.

${ }^{11}$ See, Catharine MacMillan and Richard Stone, Elements of the Law of Contract, London: University of London, (2012), p. 135 et seq.

12 Tim Lindsey, Eddy Damian, Simon Butt, Tomi Suryo Utomo, Hak Kekayaan Intelektual: Suatu Pengantar, Bandung: PT Alumni, (2011), p. 96.
} 
which is a right that is only reserved for the author so that no other party can utilise the power without the author's permission. The holder of copyright that is not the author has only a part of the exclusive rights in the form of economic rights (see, Explanation of Art. 4 of Law No. 28/2014 on Copyrights).

According to Carl-Bernd Kachlig and G.J. Churchill, exclusive rights are single rights or special rights on the author so other parties may not use it without the author's permission. ${ }^{13}$ The owner of an exclusive right is like a monopoly in the economy because the owner of a right is like a single seller. Other people have to ask permission from the owner first. British philosopher Bertrand Russel once stated that copyright is a monopoly created by law. ${ }^{14}$

However, according to Eddy Damian, copyright is a limited monopoly because work can be created at the same time (coincidence) ${ }^{15}$ With these characteristics, IPRs has exclusive rights so that the law must protect it. Therefore, Indonesian Law No.5/ 1999 regarding on Prohibition of Monopolistic Practices and Unfair Business Competition, ${ }^{16}$ provides exceptions to agreements relating to IPRs, is not qualified as a prohibited act (see, Article 50 Section b).

Exclusive rights consist of two kinds of rights, namely economic rights and moral rights. Economic rights, according to Article 8 of Law No. 28/2014 on Copyrights are the exclusive rights of the author or copyright holder to obtain economic benefits for the work. The author or copyright holder has several rights, among others:

a. Reproduction right: the right of the author to reproduce his work in any way and any amount.

b. Publishing rights: the author's right to announce, broadcast, read, exhibit the work so the others can know.

c. Mechanical right: the right of the author to copy or reproduce the work using electricity. ${ }^{17}$

Economic rights enable great opportunities for authors and copyright holders to obtain economic benefits or wealth. Article 9 of Law No. 28/2014 on Copyrights regulates economic rights that can be exercised by the author:

a. Publication of a work.

\footnotetext{
${ }^{13}$ Carl-Bernd Kachlig and G.J. Churchill, Indonesian Intellectual Property Law, Jakarta: PT Tata Nusa, (1993), p. 4.

${ }^{14}$ Bertrand Russell, Loc.Cit., Monopolies can be created by law; for example, patents, copyrights.

${ }^{15}$ Eddy Damian, Hukum Hak Cipta, Bandung: Alumni, (2005), p. 102.

${ }^{16}$ Republic of Indonesia State Gazette of 1999, Number 33. Republic of Indonesia State Gazette Additional, Number 3817.

${ }^{17}$ Rahmi Jened, Hukum Hak Cipta (Copyright's Law), Bandung: Citra Aditya Bakti, (2014), p. 125 et seq.; Damian, Op. Cit., p. 62.
} 
b. Reproduction of work in all its forms.

c. Translation of work;

d. Adaptation, arrangement or transformation of work;

e. Distribution of the work or its copy;

f. Performance of work;

g. Announcement of work;

h. Communication of work; and

i. Renting of work.

Moral rights are rights that are eternally inherent in the authors, including performers that cannot be removed or deleted without any reason, even if copyright or related rights have been transferred. Moral rights are intended for the work of the author to be recognised and respected by everyone. In moral rights there are several rights, namely: ${ }^{18}$

a. The right of paternity: the author right to claim his name on the work.

b. The right of integrity: the right of the creator to protect his reputation by maintaining the dignity and integrity of his creation.

c. The right of divulging: the author right to determine his creation will be announced or not.

d. The right to withdraw: the creator right to withdraw his creation from circulation.

Moral rights according to Indonesian Law No. 28/2014 on Copyrights cannot be transferred while the author is still alive, but the exercise of these rights can be transferred with a will or other cause by the provisions of the legislation after the author dies. ${ }^{19}$

According to the history of law, both types of rights originated from different legal tradition. Economic rights came from the Anglo Saxon legal tradition (UK Law) or the standard law system. Meanwhile, moral rights were originated from Continental European legal traditions or civil law systems, such as Italy, France, Germany, Spain, and the Netherlands.

In 1556, when copyright was first granted in England after the printing press was introduced. Copyright is given as an exclusive right to a printing company to oversee the printing and sale of books. ${ }^{20}$ On the contrary, moral rights in Continental Europe are given to the author or creator as a lifetime honour of masterpiece works in the form of classical songs, paintings and aesthetic and grand sculptures.

Differences in economic rights and moral rights have implications for the transfer and protection of author's rights. If an author wants to sell his

\footnotetext{
${ }^{18}$ Henry Soelistyo, Hak Cipta Tanpa Hak Moral, Jakarta: RajaGrafindo Persada, (2011), p. 112.

${ }^{19}$ See, Article 5 Paragraph 2 of Law No. 28 Year 2014 concerning Copyrights.

${ }^{20}$ Robert P. Merges, Peter S. Menell, Mark A. Lemley, Intellectual Property in the New Technological Age, New York: Aspen Publishers, (2003), p. 320.
} 
work, he can sell his economic rights, while moral rights cannot be sold and are valid for all time because of the paternity right.

\section{Legal Construction of Music Copyright Protection}

Before discussing this topic, we will first discuss the concept of the protection of rights. The definition of rights is always associated with the law. The existence of rights is always regulated in legal regulations. Thus, the existence of copyright depends on the rule of law, in this case the Indonesian Law No. 28/2014 on Copyrights. The protection of rights is primarily legal protection of the rights granted by the rule of law.

The meaning of protection, according to the law dictionary is the act or act of protecting. ${ }^{21}$ Meanwhile, legal protection can be interpreted as protection by law or security by using institutions and legal means. So, legal protection is an act of protection by using legal methods. The provisions in Law No. 28/2014 on Copyrights are legal guarantees to protect rights for authors and copyright holders. Legal protection for moral rights is regulated in Article 5 of Law No. 28/2014 on Copyrights, while legal protection for economic rights is regulated in Article 9 of Law No. 28/2014 on Copyrights.

The concept of legal protection, according to Law No. 28/2014 on Copyrights is related to the subject and object of creation with a specific protection period or duration. For example, music or songs as copyright objects or copyrighted works are distinguished from other copyright objects such as photographs. Also, it is also identified based on the subject. The subject of copyright is in the form of a natural person whose protection period is distinguished from a legal person or legal entity.

Work in the form of a song owned by an individual, the legal protection period is for the life of the author and continues for 70 years after the author's death, starting from January 1 of the following year. If the author is more than one person, then the legal protection period is valid for the life of the creator who died the most recent and lasted for 70 years after that, starting from January 1 of the following year. Meanwhile, if a copyright is owned or held by a legal entity, it will be valid for 50 years from the time the announcement is made. ${ }^{22}$ This protection period also applies to works in the form of photographic works, which are 50 years since the decision was first made. ${ }^{23}$

Besides, legal protection for IPRs in general, including copyrights, is based on the jurisdiction of the country or region in which national law applies (see, Art. 2 of Law No. 28/2014 on Copyrights). Through the

\footnotetext{
${ }^{21}$ See, Bryan A. Garner, ed., Black's Law Dictionary, Abridged Seventh Edition, Minnesota: West Group, (2000), p. 992.

${ }^{22}$ See, Art. 58 Par. 2 and 3 of Law No. 28 Year 2014 concerning Copyrights.

${ }^{23}$ See, Art. 59 Par. 1 of Law No. 28 Year 2014 concerning Copyrights.
} 
domestic legal system, the protection of rights can be upheld. According to WIPO (World Intellectual Property Organization), ${ }^{24}$ legal protection for IPRs is based on the principle of territoriality. Thus, strengthening national legislation and the judicial system will greatly determine the effectiveness of the protection of rights. ${ }^{25}$ The inability to realise both appropriately, the protection of rights will have no value or is useless.

The legal construction or legal framework of songs copyrights protection is intertwined in a network of legal relationship which will be described below.

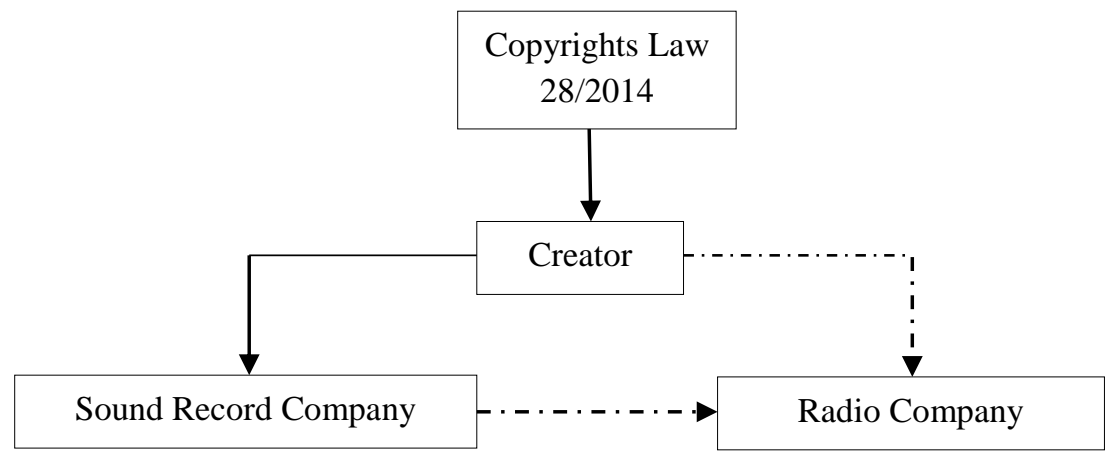

According to Indonesian Law No. 28/2014 on Copyrights, a person can become a songwriter after fulfilling the requirements and criteria in Article 1 Section 1, 2, 3 of Law No. 28/2014 on Copyrights. For the songs of his work to be enjoyed by others, the creator of music or songs as copyright owner entered into a legal relationship with a sound record company that is bound in a written agreement called a license agreement.

Based on this concept, the construction of copyright protection law with a permit or licensing mechanism. It is regulated in the provisions of Article 9 Section 2 and 3 of Law No. 28/2014 on Copyrights, which states that everyone who exercises economic rights must obtain permission from the creator or copyright holder. Therefore, anyone who is not permitted by the creator or copyright holder is prohibited from making a copy and / or commercial use of a work. Then, Article 80 Section 1 juncto Article 81

\footnotetext{
24 "Inside WIPO", https://www.wipo.int/about-wipo/en/, accessed on $6^{\text {th }}$ August 2019: WIPO is the global forum for intellectual property (IP) services, policy, information and cooperation. We are a self-funding agency of the United Nations, with 192 member states... Our mandate, governing bodies and procedures are set out in the WIPO Convention, which established WIPO in 1967.

${ }^{25}$ World Intellectual Property Organization (WIPO), WIPO Intellectual Property Handbook, Reprinted Berne: WIPO Publication No. 489 (E), (2008), p. 207.
} 
Section 1 of Law No. 28/2014 on Copyrights reaffirms the license of the copyrights holder.

Meanwhile, Law No. 28/2014 on Copyrights defined a license is written permission granted by the copyright holder or related rights owner to another party to implement economic rights for his creation or product rights related to specific conditions (see, Art. 1 Section 20 of Law No. 28/2014 on Copyrights). Copyright holders, in this case, include the author as the owner of the copyright, the party who received the right legally from the author, or other parties who received further rights from the party who won the right legitimately (see, Art. 1 Section 4 of Law No. 28/2014 on Copyrights).

Sound record companies as copyright holders are authorised to exercise economic rights of songwriter, including the right to record, reproduce, distribute, distribute and sell the recordings of the songs they produce (see, Art. 9 Section 1 of Law No. 28/2014 on Copyrights). Also, the sound record company becomes a producer who will pay at all costs in the production process, including paying royalties to the songwriter that is in return for the utilisation of economic rights.

Economic and business motives drive the relationship between songwriters and sound record companies. The author or owner of song copyright delivers his economic rights to the sound record company for profit (profit motive). Likewise sound record companies use songs commercially to obtain economic and business benefits from various sources or payments (see, Art. 1 Section 24 of Law No. 28/2014 on Copyrights).

Therefore, if there is a commercial use of music, then the user in addition to having permission is also required to pay royalties to the creator or copyright owner in return for the utilisation of the economic rights of a work. Judging from the aspect of the relationship between licensing law, the status or legal status of the creator is referred to as the licensor, while the record company is the licensee. ${ }^{26}$ Regarding the substance of the license, among other things about the term of the license and the amount of the royalty is the agreement of the parties, as long as it is in accordance with prevailing customs and meets the elements of justice (see, Art. 80 Section 3, 4, 5 of Law No. 28/2014 on Copyrights).

Sound record companies as producers; really expect their investment in the business of total sales of recorded music or songs. It is no wonder that the record company professionally chooses and decides the songs to be recorded. Benchmarks or criteria used are whether the songs can be sold in the market or not, in economic terms commonly referred to as marketable.

\footnotetext{
${ }^{26}$ Orit Afori,'Implied License: An Emerging New Standard in Copyright Law", Santa Clara
} High Technology Law Journal, 25 (2), (2009), p.42. 
Music recording producers have planned the entire process from the upstream to downstream. That is, from the preparation stage, song recording, launching, to the marketing or sales of recorded songs. Sound recording companies as song producers indeed will release of recorded songs to the public through spectacular performances and broadcast through television and radio broadcasts. In this regard, the sound record company is in a relationship with a radio company.

Radio companies need relevant music to attract the attention of their listeners and try to increase their collection of songs every time new music appears on the market. Judging from the aspect of the interests of the sound recording company, playing new songs on the radio is a promotion or advertisement. In such a situation, it can be understood that both parties need each other so that there is a relationship between the sound record company and the radio company. However, the actions of the audio record company showed the handed the new music and songs to the radio company to be aired, whether it can be legally justified.

In that connection, a clause in the license agreement between the songwriter and the record company must be reviewed. In Article 9 Section 1 of Law No. 28/2014 on Copyrights, nine items of economic rights can be granted by the creator to a record company. In this context, the songwriter can choose what it will be to the clause in the license agreement if the license agreement contains clauses on reproductive rights or reproductive rights only. Thus, sound record companies have no right to allow radio companies to utilize the author's music commercially. However, if it contains a clause to announce and distribute the songs of the songwriter, the record company has the right to allow the radio company to use it commercially.

Songwriters who have a legal relationship with radio companies are usually done by songwriters who give the record company the right to copy or reproduce. Meanwhile, the sale and distribution will be done by the songwriter himself. Meanwhile, the invention and advancement of sound recording technology have led to the making of recording equipment at prices affordable by the public. It motivates songwriters as well as music/songs to record their songs and sell directly to their fans.

Advances in technology have a direct effect on copyright protection. Information technology successfully integrates telecommunication which transfers data in digital form through the internet. It has an impact on the process of transmitting sound and images easily and quickly through a smartphone so recorded song can be done by anyone at any time easily and quickly.

A collection of music can be downloaded from the internet and digital data transmission using electronic devices. Not surprisingly, radio 
companies can easily obtain new songs without having to enter into a legal relationship with record companies and songwriters. This creates a dilemma situation. On the one hand, legally normative written agreements regarding song licenses from related parties are difficult to fulfil. On the other hand, the role of the radio company is needed for the promotion of new music. Therefore, it is reasonable if playing songs on the radio is not considered as copyright infringement.

\section{Conclusion}

Protection of music copyrights on the radio according to Indonesian Law No. 28/2014 on Copyrights is based on a permission or license which is realized in the form of a written agreement. An absence of a written agreement means not having a permit from the author so that it can be said to violate the copyright of music. The construction or legal framework for song copyright protection according to Law No. 28/2014 on Copyrights is based on relationships between legal subjects. There are at least three related legal subjects.

First, the legal relationship between the creator and the sound record company is bound in a music license agreement. The agreement determines the release of economic rights from the creator to the sound record company along with the granted rights and authority. Second is the legal relationship position between the sound record and the radio company. This legal relationship is established because of the authority given to the sound record company. The third is the legal relationship between the creator and the radio company. This legal relationship is carried out by the songwriter who already has a recorded their music or song.

It is not easy to provide legal protection for music copyrights on the radio because written agreements about song licenses may not necessarily be owned by radio companies. Moreover, radio companies easily obtain new songs through the internet and other ways of transmitting digital data. However, songwriters and sound recording companies do not question because airing music on the radio is very necessary for the promotion of new music.

\section{A. Book}

\section{Bibliography}

Damian, Eddy. (2005). Hukum Hak Cipta. Bandung: Alumni.

Garner, Bryan A. (2000). Black's Law Dictionary. Abridged Seventh Edition, Minnesota: West Group.

Jened, Rahmi. (2014). Hukum Hak Cipta (Copyright's Law). Bandung: Citra Aditya Bakti. 
Kachlig, Carl-Bernd and G.J. Churchill. (1993). Indonesian Intellectual Property Law. Jakarta: Tata Nusa.

Lindsey, Tim, Eddy Damian, Simon Butt, Tomi Suryo Utomo. (2011). Hak Kekayaan Intelektual: Suatu Pengantar. Bandung: Alumni.

MacMillan, Catharine and Richard Stone. (2012). Elements of The Law of Contract. London: University of London.

Merges, Robert P, Peter S. Menell, Mark A. Lemley. (2003). Intellectual Property in the New Technological Age. New York: Aspen Publishers.

Russell, Bertrand. (1966). Power: A New Social Analysis, New York: W.W. Norton \& Company, Inc.

Snijders, Henk and Jaap Hijma. (2010). The Netherlands New Civil Code, Jakarta: National Legal Reform Program.

Soelistyo, Henry. (2011). Hak Cipta Tanpa Hak Moral. Jakarta: Raja Grafindo Persada.

World Intellectual Property Organization. (2008). WIPO Intellectual Property Handbook. Reprinted, Berne: WIPO Publication No.489 (E).

\section{B. Journal and Article}

Ade Uswatun Sitorus, "Hak Cipta dan Perpustakaan", Jurnal Iqra', 9 (2), (2015), p.253.

Demmy Prima, "Fungsi Korelasi RRI Program Pro 1 Lestari Alamku dalam Meningkatkan Kepedulian Lingkungan Hidup di Kota Samarinda", eJournal Ilmu Komunikasi, 4 (1), (2016), p. 302.

M. Nasor, "Optimalisasi Fungsi Radio Sebagai Media Dakwah", Al-AdYaN, XII (1), (2017), p.106.

Orit Afori, "Implied License: An Emerging New Standard in Copyright Law", Santa Clara High Technology Law Journal, 25 (2), (2009).

Rezky Lendi Maramis, "Perlindungan Hukum Hak Cipta Atas Karya Musik dan Lagu Dalam Hubungan Dengan Pembayaran Royalti", Lex Privatum, II (2), (2014), p.118.

Rischy Akbar Santoso, Budi Santoso, Rinirtami, "Perlindungan Hak Komersial Pencipta Lagu Terhadap Pemanfaatan Lagu Tanpa Izin Untuk Kepentingan Komersial (Studi di: Komunitas Musik Hero Community Semarang)", Diponegoro Law Journal, 5 (3), (2016).

Ruth Dikta Novriska, "Manajemen Siaran Musik Pada Music/song Director Radio Fresh 94,3 FM Pekanbaru dalam Mempertahankan Eksistensi”, JOM FISIP, 3 (2), (2016), p.2.

Ulia, Abdullah Karim,Andik Riyanto, "Persepsi Pendengar Radio Anggota Forum Komunikasi Pemerhati Terhadap Siaran Opini Publik "Selamat Pagi Kaltim" di Pro. 1 Lembaga Penyiaran Publik Radio 
Republik Indonesia Samarinda”, eJournal Ilmu Komunikasi, 6 (4), (2018), p.165.

\section{World Wide Web}

"Inside WIPO", https://www.wipo.int/about-wipo/en/, accessed on $6^{\text {th }}$ August 2019.

"KPI Ingatkan Radio Hilangkan Kata Kasar dan Lirik Cabul"; https://www.republika.co.id/berita/ nasional/\%2010umum/18/11/09/phxgel328-kpi-ingatkan-radiohilangkan-kata-kasar-dan-lirik-cabul, accessed on $10^{\text {th }}$ July 2019.

\section{Legislation}

Law Number 5 Year 1999 concerning Prohibition of Monopolistic Practices and Unfair Business Competition.

Law Number 28 Year 2014 concerning Copyrights. 